American Journal of Environmental Sciences 1 (4): 278-285, 2005

ISSN 1553-345X

(C) 2005 Science Publications

\title{
Evaluating Methods of Estimation and Modelling Spatial Distribution of Evapotranspiration in the Middle Heihe River Basin, China
}

\author{
${ }^{1}$ Chuanyan Zhao, ${ }^{2,3}$ Zhongren Nan, ${ }^{1}$ Guodong Cheng \\ ${ }^{1}$ The State Key Lab. of Frozen Soil Eng., Cold and Arid Region Environmental and Engineering \\ Research Institute, CAS, Lanzhou 730000, China \\ ${ }^{2}$ Department of Environment Science, College of Earth and Environment Sciences, Lanzhou University, \\ Lanzhou 730000, China \\ ${ }^{3}$ National Laboratory of Western China's Environmental System, Lanzhou University, Lanzhou 730000, \\ China
}

\begin{abstract}
Seven models commonly used to estimate the daily reference evapotranspiration $\left(\mathrm{ET}_{0}\right)$ were evaluated in the middle Heihe River Basin of the arid northwestern part of China. The objectives of the study are to choose the appropriate model for estimating the areal distribution of $\mathrm{ET}_{0}$ and to explain the spatial-temporal distribution of the same through GIS in the study area. The results indicated that the FAO-Penman model is the best way to estimate $\mathrm{ET}_{0}$; its RMSE ranged from 1.11 to $1.70 \mathrm{~mm}$, and $r^{2}$ from 0.59 to 0.93 . The spatial variations of $\mathrm{ET}_{0}$ are higher in the western part than in the middleeastern part of the study area. The temporal variations of daily differences in $\mathrm{ET}_{0}$ rates are mainly due to the differences in irradiance $\left(\mathrm{R}_{\mathrm{n}}\right)$ and to daily differences in the vapor pressure deficit (D). The spatially modeled $\mathrm{ET}_{0}$ results $\left(r^{2}=0.88\right)$ are in agreement with the corresponding data in situ on the 15 th of each month.
\end{abstract}

Keywords: Reference crop evapotranspiration, Heihe River Basin, FAO-Penman equation, temporalspatial variation, geographical information system

\section{INTRODUCTION}

Increasing food production to ensure food security is a great challenge for the ever growing population of the arid northwestern part of China in the forthcoming decades. Most of the earlier studies have focused on estimation of crop water demand which is essentially governed by crop evapotranspiration $(\mathrm{ET})^{[1-6]}$. Crop ET is a function of the reference crop evapotranspiration $\left(\mathrm{ET}_{0}\right)$ and crop coefficient $\left(\mathrm{K}_{\mathrm{c}}\right)$. Over the past 50 years, many methods, namely FAO-Penman, Penman, 1982Kimberly-Penman, FAO-corrected-Penman, PenmanMonteith, Blaney-Criddle, Priestley-Taylor, FAORadiation, Hargreaves, and FAO-Blaney-Criddle, have been developed for estimating $\mathrm{ET}_{0}$. Some statistical relationships between $\mathrm{ET}_{0}$ and temperature and precipitation have been used ${ }^{[7-8]}$. These statistical relationships are specific to points or to zones where the stations were located. Therefore, it is desirable to have one method that estimates the reference crop evapotranspiration consistently well on the regional scale. Studies on spatial and temporal variations of $\mathrm{ET}_{0}$ are limited, and the spatial and temporal variations of $\mathrm{ET}_{0}$ on a regional scale are important for irrigation planning and related issues. Accordingly, there is a need for modeling $\mathrm{ET}_{0}$ through GIS to determine the spatially distributed estimation of $\mathrm{ET}_{0}$.
Irrigation is an obvious option for improving crop production in the study area. Major investments have been made in irrigation over the past 30 years by diverting surface water and extracting groundwater. As water resources becoming scarce, the region faces a serious water deficiency. The sustainability of irrigated agriculture depends primarily on the efficient management of irrigation water, which is governed by $\mathrm{ET}_{0}$. In this study, the main objective is to evaluate the methods commonly used to estimate reference crop evapotranspiration and use the most suitable one to estimate the temporal and spatial distribution of reference crop evapotranspiration.

\section{MATERIALS AND METHODS}

Study area: The middle Heihe River Basin (17.000 $\left.\mathrm{km}^{2}\right)$ is located in northwestern China between $96^{\circ} 42^{\prime}-102^{\circ} 00^{\prime} \mathrm{E}$ and $37^{\circ} 41^{\prime}-42^{\circ} 42^{\prime} \mathrm{N}$ (Fig. 1). Sandwiched between the southern Qilian Mountains and the northern Mazong Mountains, the area is like a corridor trending from northwest to southeast. The elevation ranges from 1300 to $2500 \mathrm{~m}$. The climate is characteristically arid because the area is situated in the inner part of the Asia-Europe continent. The mean annual precipitation varies from $250 \mathrm{~mm}$ in the southern mountainous area to less than $100 \mathrm{~mm}$ in the

Corresponding Author: Chuanyan Zhao, The State Key Lab. of Frozen Soil Eng., Cold and Arid Region, Environmental and Engineering Research Institute, CAS, Lanzhou 730000, China 
northern highland. Two characteristics of the precipitation deserve mention. First, the inter-annual variability in the precipitation is as high as $80 \%$. Second, over $60 \%$ of the precipitation falls between June and August. Figure 2 shows the pattern of rainfall over the year at the Zhangye meteorological station (a representative meteorological station in the study area). The mean annual air temperature is $8^{\circ} \mathrm{C}$ at the lower (northern) part of the basin and decreases to $2.1^{\circ} \mathrm{C}$ at the higher (southern) part of the basin. Zonal soil types in the area include gray-brown desert soil, gray desert soil, and mountain gray cinnamony soil. Azonal soil types consist of irrigation-warping soil, saline soil, and brown sand soil, which are embedded within the zonal soil types. Most common vegetation encountered in the area is temperate dwarf shrub and sub-shrub desert vegetation dominated by Chenopodiaceae, Zygophyllaceae, Ephedranceae, Asteraceae, Poaceae, and Leguminosae. Under the influence of the water resource distribution and human activities, there are crops and afforested areas distributed on the piedmont lower alluvial fan and fluvial plain in the area.

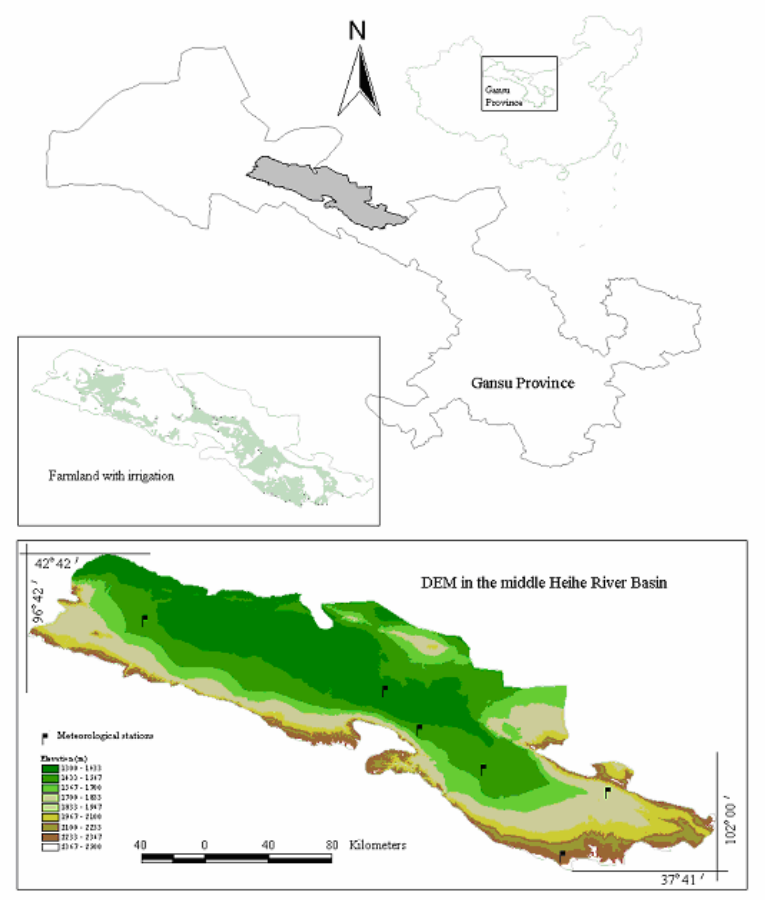

Fig. 1: Location and DEM of the middle Heihe River Basin

Data collection: The 15 weather stations were selected using a pluviometer, wind speed and direction, wet and dry bulb temperature, and evaporation pan data from in and around the middle Heihe River Basin during this study. Daily meteorological data are available for pan evaporation, precipitation, relative humidity, hours of bright sunshine, average air temperature, minimum air temperature, maximum air temperature, and wind speed. The evaporation pan, $120 \mathrm{~cm}$ in diameter and 25 $\mathrm{cm}$ deep, is placed on a short green (grass) cover and surrounded by fallow soil. The Linze Inland River Basin Comprehensive Research Station (located at $100^{\circ} 07^{\prime} \mathrm{E}, 39^{\circ} 21^{\prime} \mathrm{N}, 25 \mathrm{~km}$ from Linze station) has environmental system (ENVIS) devices from IMKO in Germany, which have been used to monitor the net radiation and soil heat flux except for general meteorological elements since 2002. The location (latitude and longitude) of each station was determined using a global positioning system (GPS). A DEM with a resolution of $30 \mathrm{~m}$ was obtained from the Remote Sensing Laboratory of the Cold and Arid Regions Environmental and Engineering Research Institute, CAS. Secondary data such as the latitude grid and longitude grid were directly derived from the DEM grid using the geographical information system (GIS, ArcInfo)

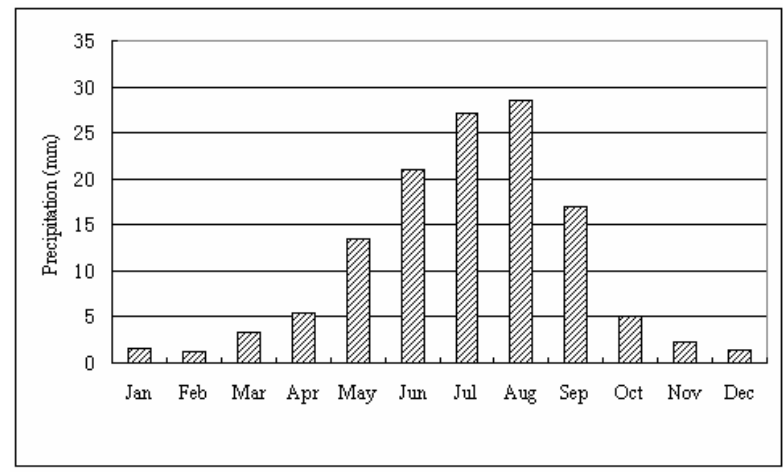

Fig. 2: Distribution of mean monthly precipitation at Zhangye meteorological station (1961-2000)

Description of models: The definition of reference crop evapotranspiration $\left(\mathrm{ET}_{0}\right)$ has been updated by Allen et al ${ }^{[9]}$. The only factors affecting $\mathrm{ET}_{0}$ are climatic parameters. Consequently, $\mathrm{ET}_{0}$ is a climatic parameter and can be computed from weather data. It expresses the evaporating power of the atmosphere at a specific location and time of the year and does not consider the crop characteristics and soil factors. A range of more or less empirical methods have been developed over the last 50 years by various scientists and specialists worldwide to estimate $\mathrm{ET}_{0}$ from different climatic variables ${ }^{[10]}$. The main climatological methods considered in the study are FAO-Penman, FAO-Radiation, Hargreaves, Penman, PenmanMonteith, Priestley-Taylor, and Blaney-Criddle. These methods are showed in Table 1.

The equations listed in Table 1 include two important variables, i.e. the net radiation $\left(R_{n}\right)$ and the soil heat flux $(G)$. The net radiation can be expressed as ${ }^{[10]}$ :

$$
R_{n}=(1-r)\left(0.25+0.5 \frac{n}{N}\right) S_{0}-\left(0.9 \frac{n}{N}+0.1\right)\left(0.34-0.14 \sqrt{e_{d}}\right) \sigma T^{4}
$$

Where:

$S_{0} \quad$ is the extraterrestrial radiation ( $\mathrm{MJ} \mathrm{m}^{-2}$ per day)

$\boldsymbol{e}_{d} \quad$ is the vapor pressure $(\mathrm{kPa})$ 
Am. J. Environ. Sci., 1 (4): 278-285, 2005

\begin{tabular}{cllr} 
Table 1: The equations of the seven models & \multicolumn{1}{c}{ Equation used } \\
\hline No. & \multicolumn{1}{c}{ Method } & \multicolumn{1}{c}{$\begin{array}{c}\text { Corresponding } \\
\text { reference }\end{array}$} \\
\hline Eq.(1) & Penman & $E T_{0}=\frac{1}{\lambda}\left[\left(\frac{\Delta}{\Delta+\gamma}\right)\left(R_{n}-G\right)+\left(\frac{\gamma}{\gamma+\Delta}\right)(6.43) W_{f} D\right]$ & {$[13]$} \\
Eq.(2) & FAO-Penman & $E T_{0}=\frac{c}{\lambda}\left[\left(\frac{\Delta}{\Delta+\lambda}\right) R_{n}+\left(\frac{\gamma}{\gamma+\Delta}\right)(2.7) W_{f} D\right]$ & {$[14-16]$} \\
Eq.(3) & Penman-Monteith & $E T_{0}=\frac{1}{\lambda}\left[\frac{\Delta\left(R_{n}-G\right)+\rho_{a} c_{p} D / r_{a}}{\Delta+\gamma\left(1+r_{s} / r_{a}\right)}\right]$ & {$[17]$} \\
Eq.(4) & Priestley-Taylor & $E T_{0}=\frac{1}{\lambda} 1.74 \frac{\Delta}{\Delta+\gamma}\left(R_{n}-G\right)$ & {$[18-19]$} \\
Eq.(5) & FAO-Radiation & $E T_{0}=b\left[\frac{\Delta}{\Delta+\gamma} S_{n}\right]-0.3$ & {$[15,20]$} \\
& & $b=1.056-0.0013 R H+0.045 U_{z}-0.0002 R H U_{z}$ & \\
& & $-0.000315 R H^{2}-0.0011 U_{z}^{2}$ & \\
Eq.(6) & Hargreaves & $E T_{0}=0.0023 S_{0} \sqrt{\delta_{T}}(T+17.8)$ & {$[21-23]$} \\
Eq.(7) & Blaney-Criddle & $E T_{0}=a_{B C}+b_{B C} f, f=p(0.46 T+8.13)$ \\
& & $a_{B C}=0.0043 R H_{\min }-(n / N)-1.41$ \\
& & $b_{B C}=0.82-0.0041 R H_{\min }+1.07(n / N)+0.065 U_{z}$ \\
$-0.006 R H_{\min }(n / N)-0.0006 R H_{\min } U_{z}$ & \\
\hline
\end{tabular}

$\sigma$

the Stefan-Boltzmann constant $\left(4.903 \times 10^{-9} \mathrm{MJ}\right.$ $\mathrm{m}^{-2} \mathrm{~K}-4$ per day)

$T \quad$ is the air temperature $(\mathrm{K})$

$r \quad$ is the reflection coefficient $(0.23)$

$n \quad$ is the bright sunshine hours per day (h)

$N \quad$ is total day length (h).

A part of the net radiation is converted into sensible heat to warm up the soil and is thus not available for evaporation. The radiation used to heat the soil (i.e., sensible heat) depends on the vegetation coverage and the physical properties of the soil (e.g., soil bulk density and soil depth). With dense vegetation, little radiation reaches the ground, and the heat storage in the soil can be often neglected ${ }^{[11]}$. To estimate the change in soil heat content for a given period, the following equation can be used:

$$
G=c_{s} d_{s} \frac{T_{2}-T_{1}}{\Delta t}
$$

Where:

$\boldsymbol{c}_{s}$ is the soil heat capacity, $1.215 \mathrm{MJ} \mathrm{m}^{-3}{ }^{\circ} \mathrm{C}^{-1}[12]$

$\boldsymbol{d}_{s}$ is the estimated effective soil depth. The effective soil depth is typically $0.5 \mathrm{~m}$ in the study area

$T_{2} \quad$ is the temperature at the end of the period considered $\left({ }^{\circ} \mathrm{C}\right)$

$T_{1} \quad$ is the temperature at the beginning of the period considered $\left({ }^{\circ} \mathrm{C}\right)$

$\Delta t \quad$ is the length of the period (days)

\section{RESULTS AND DISCUSSION}

Net radiation and soil heat flux: The net daily radiation is the fundamental variable for the simulation of evapotranspiration. However, direct measurements are not available for the study area except for Linze station, so simple radiation models become an effective alternative in estimating net radiation through observed meteorological data. The observed net daily radiation data are available for June to September 2003 at Linze station. By comparing the observed and estimated net radiation (Fig. 3), we found that Eq. (8) had a high accuracy in the study area. The soil heat flux was relatively small compared with $R_{n}$ and was underestimated by Eq. (9), when compared with the measurement. In this study, the fitness of two series of data was not good. However, the soil heat flux is not sensitive to evapotranspiration.

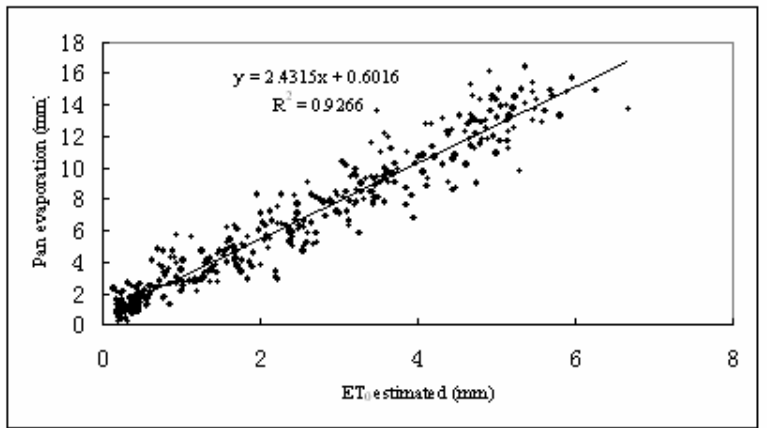

Fig. 3: Comparison between the estimated $\mathrm{ET}_{0}$ and pan evaporation at the experimental site in 2004

Selection of models: Because these models were developed in different climatic settings, their performance in a new climatic setting may vary. We used meteorological data from 2003 from five representative stations (Table 2) in the middle Heihe River Basin to calculate $\mathrm{ET}_{0}$. The estimated $\mathrm{ET}_{0}$ was validated by pan evaporation data because pans provide a measure of the combined effect of radiation, wind temperature, and humidity on the evaporation from an open water surface. Pans also respond in a similar fashion to the same climatic factors affecting $\mathrm{ET}_{0}{ }^{[24]}$. Through a comparison, the best-performing model was 
then chosen to estimate the spatial distribution of $\mathrm{ET}_{0}$ in the study area.

There are two criteria commonly used for a relative performance study of the estimation methods. One is the root mean square error (RMSE) criterion, used to compare the $\mathrm{ET}_{0}$ observed at a weather station in situ with the $\mathrm{ET}_{0}$ estimated by various climatological methods. RMSE provides a good measure of how closely two independent data sets match ${ }^{[25]}$. The other is the coefficient of determination $\left(r^{2}\right)$. The $r^{2}$ and RMSE values, as well as the slope and intercept obtained by the seven methods are shown in Table 2 .

The seven models are radiation-based (e.g. PriestleyTaylor and FAO-Radiation), temperature-based
(Hargeaves and Blaney-Criddle), or combination-based (e.g. Penman, FAO-Penman, and Penman-Monteith). Their performance at the five stations changes greatly (Fig. 4).

The Priestley-Taylor model did not perform well $\left(r^{2}=\right.$ $0.53-0.86)$, with the greatest RMSE (1.46-1.80 mm). The FAO-Penman model, in which $\mathrm{ET}_{0}$ is a function of the net solar radiation, wind speed, and vapor pressure deficit performed extremely well at the five stations, with $r^{2}$ ranging from 0.65 to 0.93 and RMSE from 1.06 to $1.47 \mathrm{~mm}$. The Hargreaves, Penman, FAO-Radiation, Blaney-Criddle, and Penman-Monteith models also did well. These methods were ranked based on the average RMSE at the five stations (Table 3).

Table2:Coefcients of determination $\left(r^{2}\right)$, RMSE, slope, and intercept between the daily $\mathrm{ET}_{0} \mathrm{~S}$ values estimated and observed at five stations (2003)

\begin{tabular}{|c|c|c|c|c|c|c|}
\hline \multicolumn{2}{|c|}{ Station } & \multirow{2}{*}{$\begin{array}{l}\text { Minle } \\
52661\end{array}$} & \multirow{2}{*}{$\begin{array}{c}\text { Shandan } \\
52652\end{array}$} & \multirow{2}{*}{$\begin{array}{c}\text { Zhangye } \\
52557\end{array}$} & \multirow{2}{*}{$\begin{array}{c}\text { Linze } \\
52546\end{array}$} & \multirow{2}{*}{$\begin{array}{c}\text { Gaotai } \\
52656\end{array}$} \\
\hline Station code & 52656 & & & & & \\
\hline Latitude & $38.45^{\circ} \mathrm{N}$ & $38.80^{\circ} \mathrm{N}$ & $38.93^{\circ} \mathrm{N}$ & $39.15^{\circ} \mathrm{N}$ & $39.37^{\circ} \mathrm{N}$ & $38.45^{\circ} \mathrm{N}$ \\
\hline Longitude & $100.82^{\circ} \mathrm{E}$ & $101.08^{\circ} \mathrm{E}$ & $100.38^{\circ} \mathrm{E}$ & $100.02^{\circ} \mathrm{E}$ & $99.83^{\circ} \mathrm{E}$ & $100.82^{\circ} \mathrm{E}$ \\
\hline Altitude (m) & 2271.00 & 1765.70 & 1483.00 & 1454.00 & 1332.20 & 2271.00 \\
\hline \multirow{7}{*}{$\begin{array}{l}\text { Correlation } \\
\text { coefficients } \\
\qquad\left(r^{2}\right)\end{array}$} & Blaney-Criddle & .82 & .66 & .67 & .87 & .64 \\
\hline & FAO-Penman & .87 & .65 & .72 & .93 & .67 \\
\hline & FAO-Radiation & .85 & .59 & .67 & .92 & .62 \\
\hline & Hargreaves & .78 & .61 & .67 & .89 & .61 \\
\hline & Penman & .85 & .62 & .69 & .92 & .64 \\
\hline & P-Monteith & .85 & .60 & .68 & .92 & .60 \\
\hline & $\begin{array}{l}\text { Priestley- } \\
\text { Taylor }\end{array}$ & .77 & .53 & .62 & .87 & .56 \\
\hline \multirow{7}{*}{ RMSE (mm) } & Blaney-Criddle & 1.31 & 1.44 & 1.36 & 1.49 & 1.33 \\
\hline & FAO-Penman & 1.11 & 1.47 & 1.25 & 1.06 & 1.27 \\
\hline & FAO-Radiation & 1.20 & 1.57 & 1.36 & 1.19 & 1.36 \\
\hline & Hargreaves & 1.45 & 1.54 & 1.37 & 1.34 & 1.38 \\
\hline & Penman & 1.18 & 1.53 & 1.33 & 1.15 & 1.33 \\
\hline & P-Monteith & 1.21 & 1.55 & 1.36 & 1.19 & 1.39 \\
\hline & $\begin{array}{l}\text { Priestley- } \\
\text { Taylor }\end{array}$ & 1.47 & 1.70 & 1.46 & 1.50 & 1.46 \\
\hline \multirow{7}{*}{ Slope } & Blaney-Criddle & .75 & .45 & .42 & .81 & .41 \\
\hline & FAO-Penman & .74 & .45 & .43 & .84 & .40 \\
\hline & FAO-Radiation & 2.11 & 1.30 & 1.25 & 2.49 & 1.17 \\
\hline & Hargreaves & 1.70 & .96 & .90 & 1.86 & .77 \\
\hline & Penman & .85 & 1.15 & 1.08 & 2.13 & .98 \\
\hline & P-Monteith & .85 & .53 & .50 & .99 & .44 \\
\hline & $\begin{array}{l}\text { Priestley- } \\
\text { Taylor }\end{array}$ & .77 & .73 & .71 & 1.43 & .62 \\
\hline \multirow{7}{*}{ Intercept } & Blaney-Criddle & -.10 & .85 & .80 & -.57 & .70 \\
\hline & FAO-Penman & -.05 & 1.19 & 1.09 & .09 & 1.06 \\
\hline & FAO-Radiation & 1.31 & 2.04 & 1.89 & 1.49 & 1.74 \\
\hline & Hargreaves & .62 & 1.38 & 1.33 & .30 & 1.24 \\
\hline & Penman & .07 & 1.18 & 1.14 & .01 & 1.08 \\
\hline & P-Monteith & .36 & 1.43 & 1.35 & .42 & 1.31 \\
\hline & $\begin{array}{l}\text { Priestley- } \\
\text { Taylor }\end{array}$ & .74 & 1.71 & 1.52 & .69 & 1.44 \\
\hline
\end{tabular}




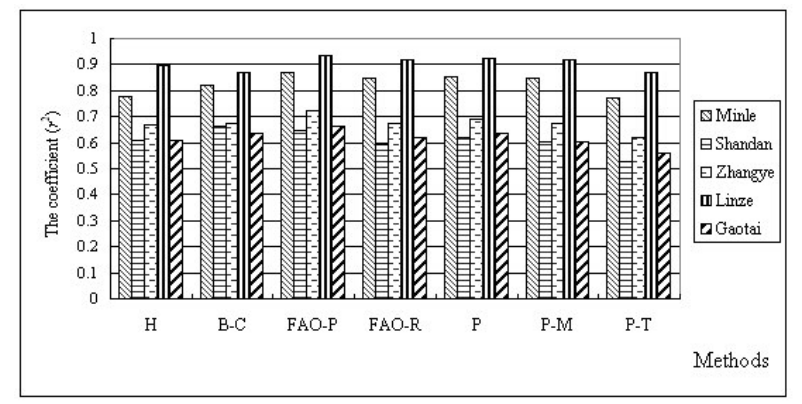

Fig. 4: Coefficients of determination $\left(r^{2}\right)$ between the estimated and observed $\mathrm{ET}_{0}$ values at five stations (B-C, Blaney-Criddle; FAO-P, FAOPenman; FAO-R, FAO-Radiation; H, Hargreaves; P, Penman; P-M, PenmanMonteith; P-T, Priestley-Taylor).

Table 3: Ranking of $\mathrm{ET}_{0}$ estimation methods on the basis of the average root mean square error at the five stations

\begin{tabular}{cccc}
\hline Rank & $\begin{array}{c}\text { Estimation } \\
\text { method }\end{array}$ & $\begin{array}{c}\text { Coefficient of } \\
\text { determination } \\
\left(r^{2}\right)\end{array}$ & $\begin{array}{c}\text { RMSE (mm } \\
\text { per day) }\end{array}$ \\
\hline 1 & FAO-Penman & 0.77 & 1.23 \\
2 & Penman & 0.74 & 1.30 \\
3 & FAO-Radiation & 0.73 & 1.34 \\
4 & P-Monteith & 0.73 & 1.34 \\
5 & Blaney-Criddle & 0.73 & 1.39 \\
6 & Hargreaves & 0.71 & 1.42 \\
7 & Priestley-Taylor & 0.67 & 1.52 \\
\hline
\end{tabular}

As stated earlier, the purpose of evaluating these commonly used models is to choose the best-performing model to estimate the spatial distribution of $\mathrm{ET}_{0}$. Our comparison of their performances demonstrates that the FAOPenman model has the best performance, with the average $r^{2}$ being the highest $(0.77)$ and the average root mean square error (RMSE) the lowest (1.23 $\mathrm{mm}$ per day). Figure 5 shows the significant correlation between the estimated and observed data at five stations. The best performance of the FAOPenman model and the availability of the parameters required by the FAO-Penman model at all the meteorological stations in the study area made this model the best choice.

Spatially distributed modeling of $\mathbf{E T}_{\mathbf{0}}$ : The FAOPenman model requires four parameters: (1) the net solar radiation $\left(R_{n}, \mathrm{MJ} \mathrm{m}^{-2}\right.$ per day); (2) the slope of the saturation vapor pressure-temperature curve $(\Delta)$; (3) the wind speed $\left(U_{z}, \mathrm{~m} \mathrm{~s}^{-1}\right)$; and (4) the vapor pressure deficit $(D, \mathrm{kPa})$. They can be calculated using models or as observed in meteorological stations.

1. Spatial interpolation of parameters required by the model

The meaning of the four parameters mentioned above and their detailed calculations are explained in Table 4. The spatial distribution of the air temperature $(T)$, the actual vapor pressure $\left(\boldsymbol{e}_{d}\right)$, the bright sunshine hours per day $(n)$, and the wind speed $\left(U_{z}\right)$ were interpolated using the Kriging method. Spatially distributed altitude data $(Z)$ and latitude data $(\varphi)$ were obtained from DEM data $(1: 100,000)$. After the basal variables were spatialized $\left(T, \boldsymbol{e}_{d}, n, U_{z}, \varphi\right.$, and $Z$ ), the other variables could be brought to the regional scale using the equations in Table 4.
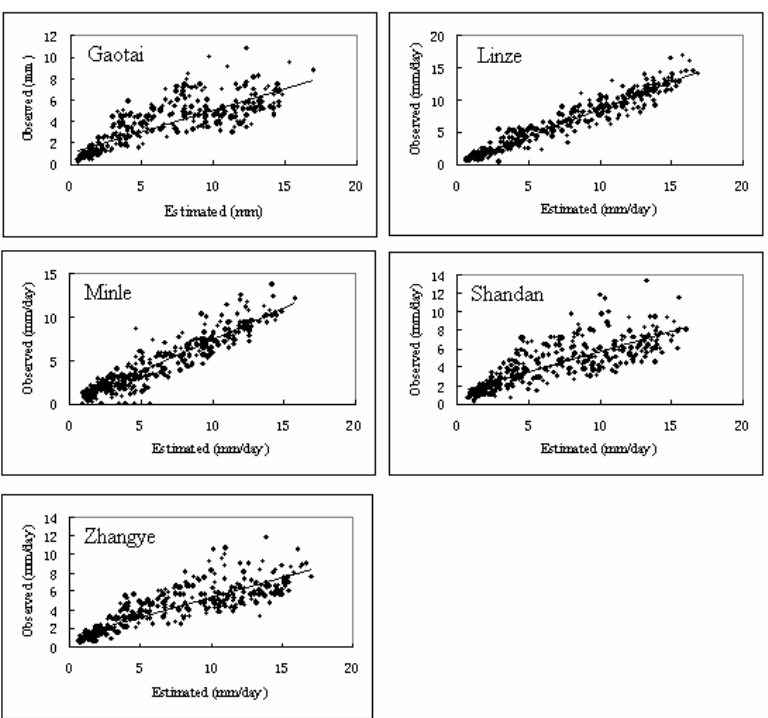

Fig.5: Scatter plot between the observed $\mathrm{ET}_{0}$ and estimated $\mathrm{ET}_{0}$ using the FAO-Penman model at five stations.

2. Spatial distribution of $\mathrm{ET}_{0}$

Finally, $\mathrm{ET}_{0}$ was spatially estimated using the FAO-Penman model, described in Table 1 (Eq. (2)). Since the purpose of modeling the spatial distribution of $\mathrm{ET}_{0}$ in the middle Heihe River Basin is to provide a baseline (or plane) for spatially mapping the water demand of crops, we focus here on the spatial distribution of $\mathrm{ET}_{0}$ during the ecologically meaningful time period, i.e., the growing season approximately from May to October. Figure 6 showed the temporalspatial distribution of $\mathrm{ET}_{0}$ on the representative date each month (15th). Spatially, the higher $\mathrm{ET}_{0}$ values are found in the western part of the Heihe River, and the lower $\mathrm{ET}_{0}$ values are found in the middle-eastern part, where the temperatures are lower because of the altitude and where it is cloudier. Figure 6 also showed that the $\mathrm{ET}_{0}$ value has a temporal variation (during the 5 days), the highest mean $\mathrm{ET}_{0}$ value, $8.78 \mathrm{~mm}$, appearing on 15th May and the lowest mean $\mathrm{ET}_{0}$ value, $3.38 \mathrm{~mm}$, being seen on 15 th October.

To test the spatially modeled $\mathrm{ET}_{0}$ results, we compared the $\mathrm{ET}_{0}$ values observed by the station on the 15 th of each month at the six representative stations (Gaotai, Zhangye, Shandan, Jiuquan, Linze, and Minle) with the spatially modeled results for the corresponding 
Am. J. Environ. Sci., 1 (4): 278-285, 2005

Table 4: Related symbols and equations in calculating $\mathrm{ET}_{0}$ using the FAO-Penman method

Variables

Equation

\begin{tabular}{|c|c|}
\hline Slope of saturation vapor curve & $\Delta=\frac{4098 e_{s}}{(237.3+T)^{2}}$ \\
\hline Psychrometric constant & $\gamma=0.0016286 \frac{P}{\lambda}$ \\
\hline Atmospheric pressure & $P=101.3\left(\frac{293-0.0065 Z}{293}\right)^{5.256}$ \\
\hline Latent heat of vaporization of water & $\lambda=2.501-0.002361 T$ \\
\hline Extraterrestrial solar radiation & $S_{0}=15.392 d r(t \sin \varphi \sin \delta+\cos \varphi \cos \delta \sin t)$ \\
\hline Relative distance between the earth and the sun & $d r=1+0.033 \cos \left(\frac{2 \pi}{365} \times J\right)$ \\
\hline Solar declination & $\delta=0.4093 \sin \left(\frac{2 \pi}{365} \times J-1.405\right)$ \\
\hline Sunset hour angle & $t=\arccos (-\tan \varphi \tan \delta)$ \\
\hline Maximum possible daylight hours & $N=\frac{24}{\pi} \times t$ \\
\hline Saturated vapor pressure & $e_{x}=0.6108 \exp \left(\frac{17.27 T}{237.3+T}\right)$ \\
\hline
\end{tabular}

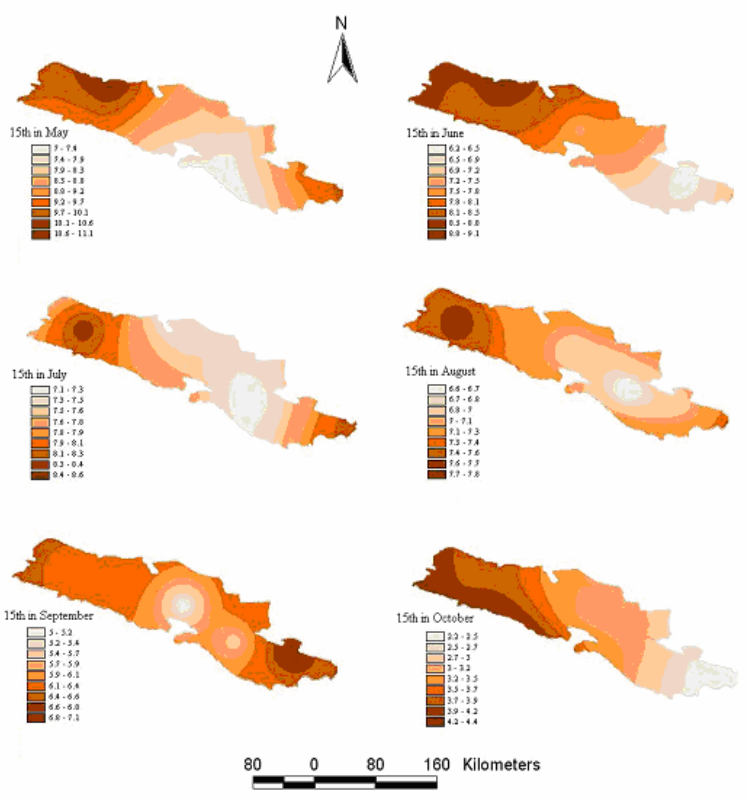

Fig.6: Distribution of daily reference crop evapo -transpiration $\left(\mathrm{ET}_{0}\right)$ from May to October in the middle Heihe River Basin.

time at the six stations (Fig. 7). The modeled $\mathrm{ET}_{0}$ values are in agreement with those measured in situ (the correlation coefficient is quite high, $r^{2}=0.88$ ), giving us confidence in the spatially-modeled $\mathrm{ET}_{0}$ results.

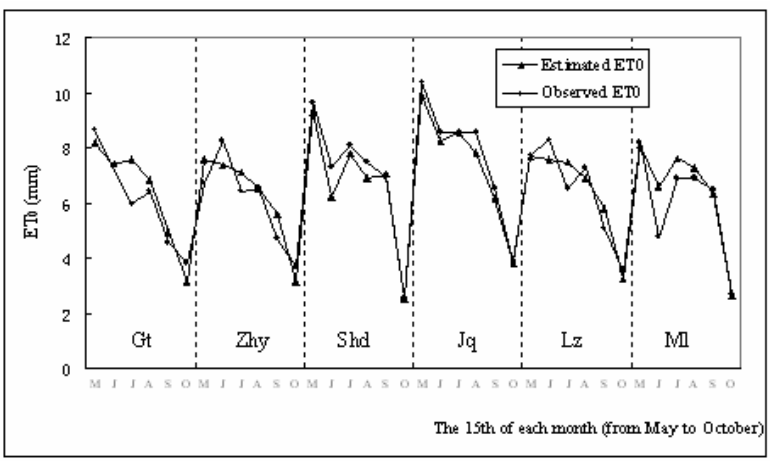

Fig.7: Comparison between measured pan evaporation and $\mathrm{ET}_{0}$ values from the resultant maps obtained using the FAO-Penman model at six meteorological stations (Gt, Gaotai; Zhy, Zhangye; Shd, Shandan; Jq, Jiuquan; Lz, Linze; Ml, Minle)

\section{CONCLUSION}

1. The best performance of the FAO-Penman model and the availability of the parameters required by 
the FAO-Penman model at all the meteorological stations in the study area made this model the best choice.

2. Our comparison shows that the net daily radiation, the fundamental variable for the simulation of evapotranspiration, was calculated with high accuracy in the study area. The modeled soil heat flux was not in agreement with that observed at the Linze station. However, the soil heat flux is not sensitive to evapotranspiration.

3. The modeled $\mathrm{ET}_{0}$ value has a temporal and spatial distribution. Spatially, the higher $\mathrm{ET}_{0}$ values are found in the western part of the Heihe River, and lower $\mathrm{ET}_{0}$ values appear in the middle-eastern part, where the temperatures, depending on the altitude, are lower and where it is cloudier. Temporally (during the 5 days), the highest mean $\mathrm{ET}_{0}$ value, $8.78 \mathrm{~mm}$, is seen on the 15th May, and the lowest mean $\mathrm{ET}_{0}$ value, $3.38 \mathrm{~mm}$, is seen on the $15 \mathrm{th}$ October.

4. The spatially modeled $\mathrm{ET}_{0}$ results were compared with the station-observed $\mathrm{ET}_{0}$ on the 15 th of each month at the six representative stations (Gaotai, Zhangye, Shandan, Jiuquan, Linze, and Minle). The modeled $\mathrm{ET}_{0}$ values during the simulated period are in agreement with those measured in situ (the correlation coefficient $r^{2}=0.88$ ), giving us confidence in the spatially modeled $\mathrm{ET}_{0}$ results.

\section{ACKNOWLEDGMENTS}

This work was supported by NSFC Project No. 40235053 and the Linze Inland River Basin Comprehensive Research Station.

\section{REFERENCES}

1. Moges, S.A., Katambara, Z., Bashar, K., 2003. Decision Support System for Estimation of Potential Evapo-transpiration in Pangani Basin. Physics and Chemistry of the Earth. 28, 927-934.

2. Smith Martin, 2000. The Application of Climatic Data for Planning and Management of Sustainable Rainfed and Irrigated Crop Production. Agricultural and Forest Meteorology. 103, 99-108.

3. Brisson Nadine, Itier Bernard, L'Hotel Jean Claude, Lorendeau Jean Yves, 1998. Parameterisation of the Shuttleworth-Wallace Model to Estimate Daily Maximum Transpiration for Use in Crop Models. Ecological Modelling, 107, 159-169.

4. Molden, D., 1997. Accounting for Water Use and Productivity. SWIM Paper 1. International Irrigation Management Institute, Colombo.
5. Su Peixi, Du Mingwu, Zhao Aifen, Zhang Xiaojun, 2002. Study on Water Requirement Law of Some Crops and Different Planting Mode in Oasis. Agricultural Research in Arid Areas. 20, 79-85 (in Chinese with English Abstract).

6. Zhao Chuanyan, Nan Zhongren, Cheng Guodong, 2005. Methods for Estimating Irrigation Needs of Spring Wheat in the Middle Heihe Basin, China. Agricultural water management, 75:54-70.

7. Chen Rensheng, 2002. Simulating Hydrological processes in the Inland River Basin (in Chinese with English abstract). PhD dissertation, Beijing, China: Cold and Arid Regions Environmental and Engineering Research Institute, CAS.

8. Wang K., Cheng Guodong, Jiang Hao, Zhang Lijie, 2003. Atmospheric hydrologic cycle over the Qilian Heihe Valley (in Chinese with English Abstract). Advances in Water Science. 14, 91-96.

9. Allen, R.G., Smith, M., Perrier, A., and Pereira, L.S., 1994. An update for the definition of reference evapotranspiration. ICID Bulletin. 43, 134.

10. Shuttleworth, W.J., 1992. Evaporation. In: Maidment, D.R. (Ed), Handbook of Hydrology. New York, pp. 4.1-4.53.

11. Shuttleworth, W.J., Gash, J.H.C., Lioyd, C.R., Moore, C.J., Roberts, J., Marques, A. de O., Fisch, G., Silva Filho, V. de P., Ribeiro, M.N.G., Molion, L.C.B., Nobre, J.C., Sa, L.D.A. de, Cabral, O.M.R., Patel, S.R., and Mordas, J.C., 1984. Observations of Radiation Exchange above and below Amazonian Rainforest. Q.J.R. Meteorol. Soc., 110, 1163-1169.

12. Zhangye Soil Agency, 1986. Soils in Zhangye Region (in Chinese).

13. Penman, H.L., 1963. Vegetation and Hydrology. Tech. Comm. No. 53, Commonwealth Bureau of Soils, Harpenden, UK, pp.125.

14. Doorenboss, J., Pruitt, W.O., 1975. Guidelines for Prediction Crop Water Requirements. FAO Irrig. Drain. Paper No. 24. FAO Rome, Italy, pp.179.

15. Doorenboss, J., Pruitt, W.O., 1977. Guidelines for Prediction Crop Water Requirements. Revised 1997.

16. Penman, H.L., 1948. Natural Evaporation from Open Water, Bare Soil and Grass. Proc. R. Soc. Lond. A193, 116-140.

17. Monteith, J.L., 1965. The State and Movement of Water in Living Organisms. In: Proceedings of the XIX Symposium of Society for Experimental Biology, Swansea, Cambridge University Press, Cambridge, pp.205-234. 
18. Priestley, C.H.B., Taylor, R.J., 1972. On the Assessment of Surface Heat Flux and Evaporation Using Large Scale Parameters. Mon. Weath. Rev. 100, 81-92.

19. Jensen, M.E., Burman, R.D., and Allen, R.G., 1990. Evapotranspiration and Irrigation Water Requirements ASCE Manual 70, p. 332.

20. Frevert, D.K., Hill, R.W., and Braaten, B.C., 1983. Estimation of FAO Evapotranspiration Coefficients. J. Irrig. And Drain Engrg., ASCE 109(IR2): 265-270.

21. Hargreaves, G.H., Hargreaves, G.L., Riley, J.P., 1985. Agricultural Benefits for Senegal River Basin. J. Irrig. Drain. Eng., ASCE, U.S.A. 111, 113-124.
22. Hargreaves, G.H., Samani, Z.A., 1982. Estimating Potential Evapotranspiration. Tech. Note. J. Irrig. Drain. Eng.

23. Hargreaves, G.H., Samani, Z.A., 1985. Reference Crop Evapotranspiration from Temperature. Applied Eng. Agric. 1, 96-99.

24. Allen, R., Pereira, L.A., Raes, D., Smith, M., 1998. Crop Evapotranspiration. FAO Irrigation and Drainage Paper 56, Rome, pp. 293.

25. Ventura, F., Spano, D., Duce, P., Snyder, R.L., 1999. An Evaluation of Common Evapotranspiration Equations. Irrig. Sci. 18, 163170. 